\title{
Starch and fibre intake and glucose postprandial response of dogs
}

\author{
Consumo de amido e fibra e a resposta pós-prandial de glicose de cães
}

\author{
Mariana Monti ${ }^{I}$ Guilherme Roberto Palumbo ${ }^{I}$ Mariana Vieira de Paula Pinto ${ }^{I}$ \\ Thaila Cristina Putarov ${ }^{I}$ Bruna Agy Loureiro ${ }^{I}$ Márcia de Oliveira Sampaio Gomes ${ }^{I I}$ \\ Gener Tadeu Pereira ${ }^{\mathrm{I}}$ Aulus Cavalieri Carciofi ${ }^{{ }^{*}}$
}

\section{ABSTRACT}

Fibre has been studied to reduce the postprandial

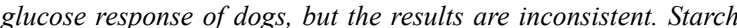
intake, however, was not properly considered in the published studies. The effects of starch and fibre intake on the postprandial glucose response were studied in non-obese adult dogs. Cellulose (CEL), carboxymethylcellulose $(C M C)$, pea fibre (PE) and sugarcane fibre (SCF) were combined to form six diets with starch contents ranging from $33 \%$ to $42 \%: S C F+C E L$ and $P E+C E L$ diets, both with high insoluble fibre (IF=22\%) and low soluble fibre $(S F=2.5 \%)$ content; $S C F+C M C$ and $P E+C M C$ diets with high $S F$ $(S F=4.5 \% ; I F=19 \%)$ content; and CMC and CEL diets with low dietary fibre (14\%) content. The diets were fed in two amounts, providing an intake of $9.5 \mathrm{~g}$ or $12.5 \mathrm{~g}$ of starch ( $\mathrm{kg} 0.75)-1$ day-1, totaling 12 treatments. Each diet was fed to six dogs conditioned to consume all of the daily food in 10min. Their plasma glucose levels were measured before and during 480min after food intake. Results of fibre and starch intake and their interactions were compared by repeated measures ANOVA and the Tukey test $(P<0.05)$. Fibre intake did not change the glucose postprandial responses $(P>0.05)$. High-dose starch intake, however, induced a higher glycaemia at 180 and 240min after the meal and a greater maximal glycaemia and greater area under the glucose curve $(P<0.05)$. A range in insoluble and soluble fibre intake does not change postprandial glucose response, and the amount of starch intake is a main factor for the postprandial glucose response of healthy non-obese dogs.

Key words: dietary fibre, glycaemia, metabolic response, metabolisable energy.

RESUMO

Fibras têm sido estudadas como opção para reduzir a resposta glicêmica pós-prandial de cães, mas os resultados obtidos têm sido inconsistentes. A ingestão de amido, no entanto, não tem sido adequadamente considerada na interpretação dos resultados de algumas dessas pesquisas. O presente estudo investigou, em cães adultos não obesos, os efeitos da ingestão de amido e fibra sobre a resposta pós-prandial. Celulose (CEL), carboximetilcelulose (CMC), fibra de ervilha (PE) e fibra de cana-de-açúcar (SCF) foram combinadas, gerando seis dietas com $33 \%$ a $42 \%$ de amido: dietas $S C F+C E L$ e PE+CEL com alta fibra insolúvel $(I F=22 \%) e$ baixa fibra solúvel $(S F=2,5 \%)$; dietas $S C F+C M C$ e $P E+C M C$ com alta fibra solúvel $(S F=4,5 \% ; I F=19 \%)$; dietas $C M C$ e CEL como controles baixa fibra (14\%). As dietas foram fornecidas aos cães em duas quantidades, resultando na ingestão de 9,5g ou $12,5 \mathrm{~g}$ de amido (kg0,75)-1 dia-1, gerando um total de 12 tratamentos. Cada tratamento foi fornecido a seis cães, condicionados a ingerir todo o alimento do dia num período de 10min. A glicose plasmática foi medida em jejum e durante 480 min após a refeição. Os resultados foram analisados por análise de variância de medidas repetidas, considerando-se os feitos da ingestão de amido e fibra, e suas interações, sendo as médias comparadas pelo teste de Tukey $(P<0,05)$. A ingestão de fibra não alterou a resposta pós-prandial de glicose $(P>0,05)$. O consumo da dose elevada de amido, no entanto, resultou em maiores glicemias aos 180 e 240min, maior glicemia máxima e maior área abaixo da curva de glicose $(P<0,05)$. Verificou-se que a quantidade ingerida de amido é mais importante que o consumo de fibra para a resposta glicêmica pósprandial de cães não obesos.

Palavras-chave: energia metabolizável, fibra alimentar, glicemia, respostas metabólicas.

\section{INTRODUCTION}

In response to the increase in canine health problems related to glucose intolerance (e.g., obesity and diabetes mellitus), there is an interest in investigating diets that favour glycaemic control

\footnotetext{
${ }^{\mathrm{I}}$ Faculdade de Ciências Agrárias e Veterinárias (FCAV), Universidade Estadual Paulista (UNESP), Via de Acesso Prof. Paulo Donato Castellane, s/n, 14884-900, Jaboticabal, SP, Brasil. E-mail: aulus.carciofi@gmail.com. *Corresponding author.

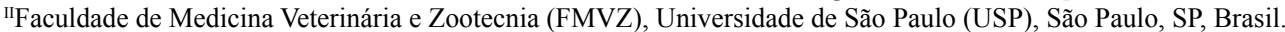


(CARCIOFI et al., 2008). Studying the glucose and insulin responses to a meal relies on evaluating carbohydrate metabolism: as faster and more complete the digestion and absorption of starch is, the greater the postprandial responses of humans (WOLEVER \& BOLOGNESI, 1996) and dogs (CARCIOFI et al., 2008) are. Other dietary factors also influence the postprandial glycaemic responses and depend on an integrated evaluation of the diet, including starch-intrinsic factors such as digestion rates (CARCIOFI et al., 2008) and amyloseto-amylopectin ratios (BILIADERIS, 1991) as well as extrinsic influences, such as the ingested amount, the extent of food processing and diet composition (HEATON et al., 1988; WOLEVER \& BOLOGNESI, 1996; NGUYEN et al., 1998).

Regarding diet composition, increasing the dietary fibre content has been explored for dogs and cats as a nutritional tool to reduce postprandial glucose responses, but not always showing significant results (MASSIMINO et al., 1998; FISCHER et al., 2012). In several of these studies, fibre was added to the diet replacing the starch sources, attempting to control the amounts of protein and fat in the experimental foods. Nevertheless, this substitution of starch by fibre in the experimental design induced the ingestion of different amounts of starch because the diets were given to dogs based on DM or metabolisable energy intake, and their starch intake was not always kept constant between treatments. In one study (HOENIG et al., 2001) the effects of different sources of fibre were evaluated using dogs, including guar gum (high solubility and fermentability), beet pulp (moderate solubility and fermentability), and cellulose (low solubility and fermentability), and the different sources were included in diets in low, moderate, and high amounts. The authors concluded that high fibre diets did not affect glucose tolerance, but no reference was made to the starch content of these diets. Another study (NGUYEN et al., 1994) evaluated the effect of the meal composition on the postprandial glycaemic and insulinemic responses of dogs but also did not report the amount of starch intake during the evaluation.

For humans, it is well know that the amount of starch eaten is one of the main predictors of the glucose response to the meal (WOLEVER \& BOLOGNESI, 1996), but unfortunately, the starch intake in experiments using dogs has not been described or controlled sufficiently to allow an understanding of its influence. Considering this, using diets with different starch and fibre inclusion amounts and different fibre types the present study evaluated the effect of the intakes of starch and fibre on the postprandial glycaemic response of non-obese adult dogs.

\section{EXPERIMENTAL METHODS}

Animals, diets and experimental design

The study was conducted in the Laboratory of Research on Nutrition and Nutritional Diseases of Dogs and Cats of the UNESP, Jaboticabal, Brasil.

The experiment was conducted using six adult clinically healthy beagle dogs, with an average body weight of $11.3 \pm 0.5 \mathrm{~kg}$, a mean age of $3.3 \pm 0.2$ years, and a mean body condition score of $5.0 \pm 0.2$ on a nine-point scale (LAFLAMME, 1997). The dogs were housed in pairs in $1.5 \times 4.0 \mathrm{~m}$ kennels with a solarium and were randomly allotted to the experimental treatments. The dogs were exercised daily in a $200 \mathrm{~m}^{2}$ grassy area.

The dietary treatments included the following four fibre sources: an insoluble nonfermentable purified source - purified cellulose (CEL; ARBOCEL BWW 40C, J. Rettenmaier Latino Americana Ltda, Diadema, SP, Brasil); a soluble, highly viscous and non-fermentable purified source - carboxymethylcellulose (CMC; CEKOL 700, CPKelco, Limeira, SP, Brasil); an insoluble natural source - pea fibre (PE; Dilumix, Leme, SP, Brasil); an insoluble and long-length natural source - sugarcane fibre (SCF; Vit2be Fiber, Dilumix, Leme, SP, Brasil). These fibres were included in complete kibbled diets balanced for dog maintenance (FEDIAF, 2008). Combining these four fibre sources, six diets were formulated. Two diets presented high insoluble fibre $(22 \%)$ and low soluble fibre $(2.5 \%)$ content, being one formulated with SCF $(12 \%$ of inclusion, asfed basis) and CEL (2.2\%), and the other with PE (12.8\%) and CEL (2.2\%). Two diets presented high soluble (4.5\%) and moderate insoluble fibre (19\%), one including SCF $(12 \%)$ and CMC $(2.8 \%)$, and the other PE (12.8\%) and CMC (2.8\%). Two diets was used as control, lower fibre diets, one including $\mathrm{CMC}$ $(2.8 \%)$ and the other CEL $(2.2 \%)$. The formulation and chemical composition of the experimental diets are presented on table 1. The four diets supplemented with fibre $(\mathrm{SCF}+\mathrm{CEL}, \mathrm{PE}+\mathrm{CEL}, \mathrm{SCF}+\mathrm{CMC}$, and $\mathrm{PE}+\mathrm{CMC}$ ) showed similar nutrient and total dietary fibre contents, varying only on the proportion soluble: insoluble fibre. The other two diets (CMC and CEL) had the same protein and fat, but less dietary fibre and more starch, as they were used as controls.

The diets were produced in the extruder facility of the College of Agrarian and Veterinarian Sciences of Universidade Estadual Paulista. The 
Table 1 - Ingredient and chemical composition of the experimental diets.

\begin{tabular}{|c|c|c|c|c|c|c|}
\hline \multirow{2}{*}{$\begin{array}{l}\text { Ingredients, \% } \\
\text { (as-fed basis) }\end{array}$} & \multicolumn{6}{|c|}{ - } \\
\hline & $\mathrm{SCF}+\mathrm{CEL}$ & $\mathrm{SCF}+\mathrm{CMC}$ & $\mathrm{PE}+\mathrm{CEL}$ & $\mathrm{PE}+\mathrm{CMC}$ & CEL & $\mathrm{CMC}$ \\
\hline Sugarcane fibre & 11.98 & 11.98 & - & - & - & - \\
\hline Pea Fibre & - & - & 12.76 & 12.77 & - & - \\
\hline Cellulose & 2.17 & - & 2.17 & - & 2.17 & - \\
\hline Caboxymethilcellulose & - & 2.88 & - & 2.88 & - & 2.88 \\
\hline Poultry by-product meal & 24.92 & 24.92 & 24.09 & 24.10 & 25.15 & 25.16 \\
\hline Broken rice & 18.00 & 18.00 & 18.00 & 18.00 & 18.00 & 18.00 \\
\hline Maize & 18.00 & 18.00 & 18.00 & 18.00 & 18.00 & 18.00 \\
\hline Gluten Meal 60\% & 9.00 & 9.00 & 9.00 & 9.00 & 9.00 & 9.00 \\
\hline Poultry fat & 4.00 & 4.00 & 4.00 & 4.00 & 4.00 & 4.00 \\
\hline Maize starch & 3.21 & 2.49 & 3.25 & 2.53 & 14.96 & 14.24 \\
\hline Brewer's yeast & 2.00 & 2.00 & 2.00 & 2.00 & 2.00 & 2.00 \\
\hline Liquid Palatant & 2.00 & 2.00 & 2.00 & 2.00 & 2.00 & 2.00 \\
\hline Vitamin/mineral premix ${ }^{2}$ & 1.87 & 1.87 & 1.87 & 1.87 & 1.87 & 1.87 \\
\hline Potassium chloride & 0.40 & 0.40 & 0.40 & 0.40 & 0.40 & 0.40 \\
\hline Mould inhibitor $^{3}$ & 0.30 & 0.30 & 0.30 & 0.30 & 0.30 & 0.30 \\
\hline Antioxidant $^{4}$ & 0.15 & 0.15 & 0.15 & 0.15 & 0.15 & 0.15 \\
\hline Total & 100 & 100 & 100 & 100 & 100 & 100 \\
\hline & $----\cdot$ & ed chemic & sition, $\%$ & $(\operatorname{sis})^{5}-$ & 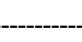 & ------ \\
\hline Dry matter & 90.62 & 92.70 & 91.43 & 90.11 & 92.28 & 90.80 \\
\hline Crude protein & 30.93 & 29.33 & 29.90 & 31.18 & 29.31 & 31.28 \\
\hline Acid-hydrolysed fat & 10.45 & 11.56 & 10.88 & 11.37 & 11.05 & 11.60 \\
\hline Starch & 34.06 & 33.88 & 32.57 & 32.11 & 41.35 & 42.44 \\
\hline Total dietary fibre & 24.12 & 23.40 & 24.61 & 23.63 & 14.12 & 14.22 \\
\hline Insoluble dietary fibre & 21.24 & 18.55 & 22.5 & 19.46 & 11.20 & 9.55 \\
\hline Soluble dietary fibre & 2.88 & 4.85 & 2.11 & 4.17 & 2.92 & 4.67 \\
\hline Gross energy $(\mathrm{kJ} / \mathrm{kg})$ & 13.89 & 14.07 & 14.03 & 14.15 & 15.81 & 15.03 \\
\hline Starch gelatinization $(\%)$ & 96.50 & 97.30 & 93.50 & 98.20 & 98.40 & 95.70 \\
\hline
\end{tabular}

1 - Diets: SCF+CEL - Addition of sugarcane fibre and cellulose; SCF+CMC - addition of sugarcane fibre and caboxymethilcellulose; PE +CEL - addition of pea fibre and cellulose; PE+CMC - addition of pea fibre and carboxymethilcellulose; CEL - addition of cellulose; CMC - addition of carboxymethilcellulose. 2 - Per kg of diet: iron, 120mg; copper, 15mg; magnesium, 75mg; zinc, 150mg; iodine, 2mg; selenium, 0.3mg; vitamin A, 18,000IU; vitamin D3, 1,000IU; vitamin E, 100IU; vitamin K, 2mg; biotin, 0.6mg; thiamine, 20mg; riboflavin, 100mg; pantothenic acid, 50mg; niacin, 75mg; vitamin B6, 6mg; folic acid, 4mg; vitamin B12, $0.1 \mathrm{mg}$. 3 - Fylax: Agroceres Animal Nutrition Ltda (Composition: propionic acid). 4 - Seldox: Agroceres Animal Nutrition Ltda (Composition: BHT-butylated hydroxytoluene). 5 - Analysed in duplicate.

ingredients were mixed and ground using a hammer mill (Model 4, D’Andrea, Limeira, Brasil) fitted with a $0.8-\mathrm{mm}$ screen sieve. Diets were extruded under identical processing conditions using a single-screw extruder (Mab 400S, Extrucenter, Monte Alto, Brasil) with an average extrusion capacity of $150 \mathrm{~kg} \mathrm{~h}-1$. A laboratory-scale complete extrusion system was used, which has the same components and standards of operation as the extruders used for commercial production. The manufacturing process was controlled by adjusting the kibble density to between 390 and $410 \mathrm{~g} \mathrm{~L}-1$ (as-is basis) every 20min to ensure consistent cooking and kibble quality (size and expansion). The extruder pre-conditioning temperature was maintained above $90^{\circ} \mathrm{C}$. The water and steam additions, screw speed and food flux were adjusted according to the dietary formulations, and the extrusion temperature varied between 125 and $135^{\circ} \mathrm{C}$. Degree of starch gelatinisation was adequate in all of the diets, with values of greater than $90 \%$ (SA et al., 2013).

Foods were analyzed for DM by ovendrying the sample (method 934.01) and conversion to ash by muffle furnace incineration (method 942.05). Crude protein (CP) was analyzed by the Kjeldahl method (method 954.01), and acid hydrolyzed fat was assessed using a Soxhlet apparatus (method 954.02) according to the Association of Official Analytical Chemists (AOAC, 1995). Organic matter (OM) was calculated as DM-ash. Dietary fibre (total, soluble, and insoluble) was measured by using a combination 
of enzymatic and gravimetric procedures (AOAC, method 991.43, 1995). Total amount of starch was determined according to the method described by HENDRIX (1995). The degree of gelatinization of the starch of the experimental diets was determined by the amyloglucosidase method (SA et al., 2013). All analyses were carried out in duplicate and repeated when the coefficient of variation was higher than $5 \%$.

To study the postprandial glucose response, the six experimental diets were fed in two amounts to the dogs using a $6 \times 2$ factorial arrangement (six diets and two dosages), for a total of 12 experimental treatments. The amount of each diet offered was defined according to its starch content, and the dogs were fed with calculated amounts to attain intakes of $9.5 \mathrm{~g}$ or $12.5 \mathrm{~g}$ of starch $(\mathrm{kg} 0.75)-1$ day- 1 . To this, first the amount of starch to be fed was defined multiplying 9.5 or $12.5 \mathrm{~g}$ by the dog metabolic weight (body weight, kg0.75). After defined the desired amount of starch, the amount of daily food provided for each dog was calculated dividing the amount of starch to be fed by the starch content of the food. This amount of starch intake resulted on the consumption of approximately $385 \mathrm{~kJ}$ and $505 \mathrm{~kJ}$ of metabolisable energy ( $\mathrm{kg} 0.75)-1$ day-1, respectively, what is considered physiological for dogs at maintenance (NRC, 2006). A washout period of at least one week was done between each postprandial evaluation, during this period the dogs was fed with their normal kibble diet used in the kennel.

After five days of adaptation to the diet (NGUYEN et al., 1998a) and provided amount, the postprandial glucose responses of the dogs were evaluated (CARCIOFI et al., 2008). Before the test, dogs were conditioned to ingest all of the food within 10 minutes. Dogs that took longer than $10 \mathrm{~min}$ to consume the total amount of food were not tested, and the procedure was repeated on the following day. Afterward, the animals were deprived of food for the 24-hour period prior to the evaluation. On the day of the test, each dog was aseptically catheterized using a peripheral intravenous catheter inserted into the cephalic vein (Angiocath 20GA x 1.16in., Becton Dickinson, USA). Blood samples were taken prefeeding (baseline sample, time 0 ) and 5, 10, 15, 30, $60,120,180,240,300,360,420$, and $480 \mathrm{~min}$ postfeeding. The time was computed starting immediately at the end of the meal. The blood was always collected at the same time, beginning at 8:00 am. Each sample $(1.5 \mathrm{~mL})$ was collected in a Na-heparin tube and centrifuged (2,000 x G for $5 \mathrm{~min}$ ), and then, the plasma was placed in polypropylene tubes and maintained under refrigeration $\left(4^{\circ} \mathrm{C}\right)$ for a maximum of two hours before analysis. The plasma glucose concentrations were determined with glucose oxidase tests (GODANA, Labtest Diagnóstica S.A., Lagoa Santa, Brasil) using a semi-automated glucose analyser (Labquest model BIO-2000, Labtest Diagnóstica S.A., Lagoa Santa, Brasil). All of the analyses were conducted in duplicate and were repeated when the coefficient of variation was greater than $5 \%$.

The changes in the plasma glucose concentrations were calculated for each postprandial period. Comparisons between the responses were made for mean and maximal increases, the mean and maximal incremental increases (the difference between the absolute glucose concentration in the sample and the baseline glucose concentration), and time to peak increase. The integrated areas under the postprandial glucose response curves were calculated using the trapezoidal method. In addition to measuring the total area under the curve (AUC from 0 to $480 \mathrm{~min}$ ), other selected intervals were also calculated. ORIGIN software (Microcal Software, Inc. Version 6.0, USA) was used to compute the AUC values.

\section{Statistical analysis}

The data were analyzed using the GLM procedure of the SAS software (Version 8.0, SAS Institute, Cary, NC, USA). The experimental unit was one dog. All of the dogs received all of the combinations of treatments (ZOLMAN, 1993). The model sums of squares were separated into dietary and animal effects and their interactions. The interactions among the variables tested (diet and ingested amount) were analyzed using the SLICE statement. Repeated measures analysis of variance with one inter-animal factor (diet) and one intra-animal factor (time of measurement) was the statistical method chosen to evaluate the effects of diet and time on the postprandial plasma changes. Pair-wise means comparisons were made using the Tukey test when the ANOVA F-test results were statistically significant. Values of $\mathrm{P}<0.05$ were considered significant.

\section{RESULTS}

The dogs adequately consumed their diets in the $10 \mathrm{~min}$ allowed. When the dogs were arbitrarily fed the lower amount of starch $(9.5 \mathrm{~g}$ of starch (kg0.75)-1 day-1), they ingested less energy, starch, and fibre than when they were fed the higher starch dosage, as expected ( $\mathrm{P}<0.05$; Table 2$)$. In addition, when the dogs were fed with low-fibre diets (CEL and CMC foods), they ingested less fibre than when they were fed with the diets supplemented with SCF or PE 
Table 2 - Nutrient intake and glucose postprandial response of dogs fed with experimental diets with different amounts of fibres of different solubilities, fed to achieve high $\left(12.5 \mathrm{~g}\right.$ of starch $\left(\mathrm{kg}^{0.75}\right)^{-1}$ day) and low $\left(9.5 \mathrm{~g} \text { of starch }\left(\mathrm{kg}^{0.75}\right)^{-1} \text { day }\right)^{-1}$ starch intake.

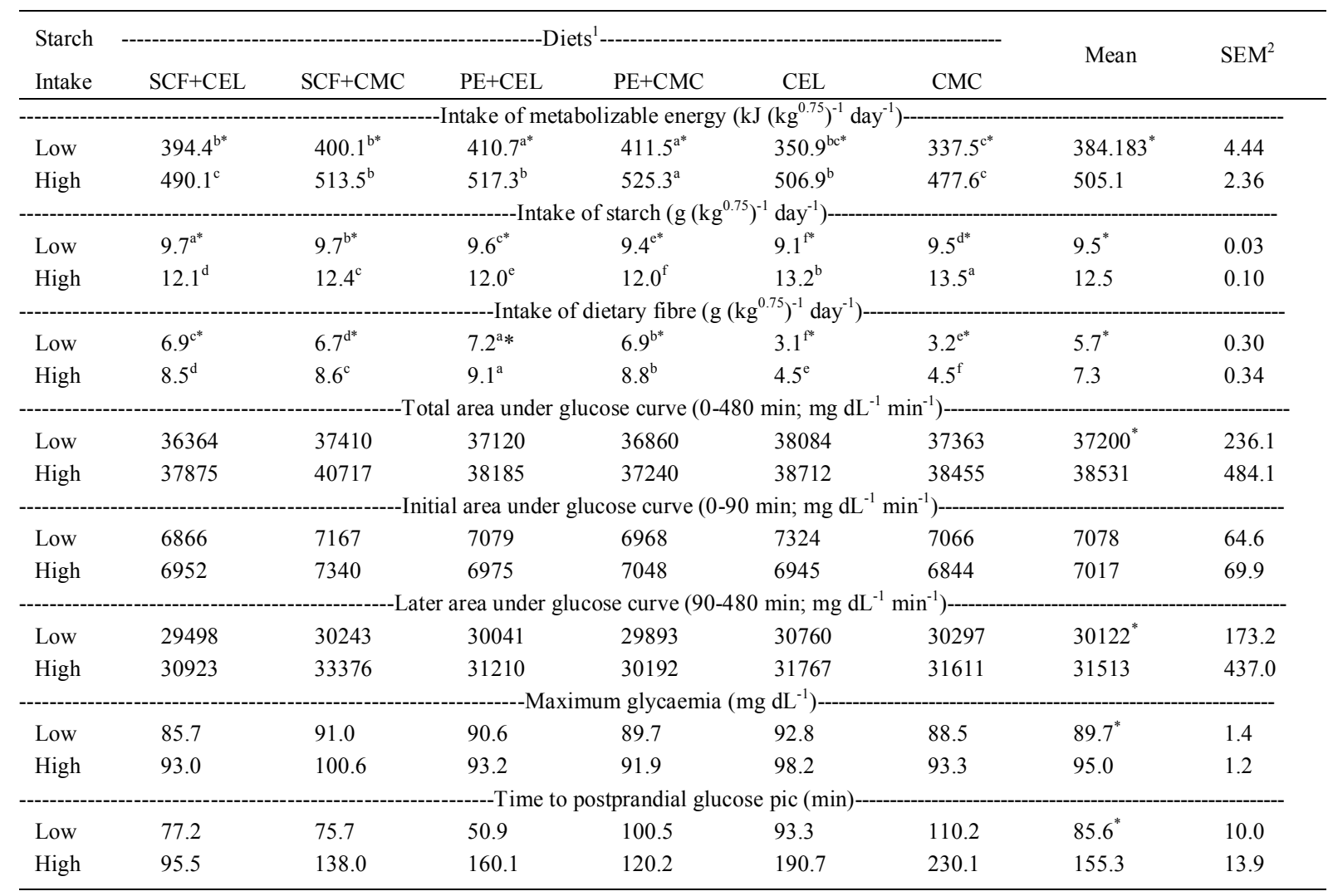

1 - Diets: SCF+CEL - Addition of sugarcane fibre and cellulose; SCF+CMC - addition of sugarcane fibre and caboxymethilcellulose; $\mathrm{PE}+\mathrm{CEL}$ - addition of pea fibre and cellulose; PE+CMC - addition of pea fibre and carboxymethilcellulose; CEL - addition of cellulose; $\mathrm{CMC}$ - addition of carboxymethilcellulose. 2 - Standard error of mean, $\mathrm{n}=6$ animals per diet. * Differences between starch intake amounts $(\mathrm{P}<0.05) .{ }^{\mathrm{a}, \mathrm{b}, \mathrm{c}}$ Means in the row not sharing a common letter differs $(\mathrm{P}<0.05)$.

$(\mathrm{P}<0.05)$. The faeces production during the study was adequate, without episodes of diarrhea or soft faeces. There was no effect of the diet (fibre addition or fibre type) or of the diet-versus-time interaction for any of the evaluated traits $(\mathrm{P}=0.7)$. For this reason, the effect of starch intake amount was evaluated independently of diet (fibre type or dietary amount). When the dogs were fed the higher amount of starch $(12.5 \mathrm{~g}$ of starch (kg0.75)-1 day), regardless of the diet and the fibre type, they presented a higher glucose AUC from 0-480min, a higher AUC from 90-480min, a higher mean and maximal glycaemia, and a prolonged time to the glucose peak $(\mathrm{P}<0.05)$. An interaction between time and the amount of starch consumed was verified $(\mathrm{P}=0.001)$; at $180 \mathrm{~min}$ and $240 \mathrm{~min}$ after the meal, when the dogs had been fed the higher amount of starch, they exhibited a higher level of glycaemia than when they had been fed with the lower amount of starch $(\mathrm{P}<0.05$; Figure 1).

\section{DISCUSSION}

The results showed that changing the dietary fibre intake from 3.1g (kg0.75)-1 day-1 (CEL diet) to $9.1 \mathrm{~g}(\mathrm{~kg} 0.75)-1$ day-1 (PE+CEL diet) did not change the postprandial glucose response. This intake change is considered a substantial increase because the high-fibre diets contained approximately $24 \%$ dietary fibre. Soluble fibre consumption also did not change the glucose meal response, even increasing it consumption from $0.7 \mathrm{~g}$ ( $\mathrm{kg} 0.75)-1$ day-1 (CEL diet) to $1.7 \mathrm{~g}(\mathrm{~kg} 0.75)-1$ day-1 (SCF+CMC diet) dogs did not shown alteration in any evaluated parameters. Other previous studies using dogs also did not find effect of fibre on the postprandial glucose response (MASKELL et al., 1994; HOENIG et al., 2001). Evaluating beet pulp, guar gum and inulin incorporated in the basal diet of healthy dogs, DIEZ et al. (1998) did not find any changes on glucose meal response 


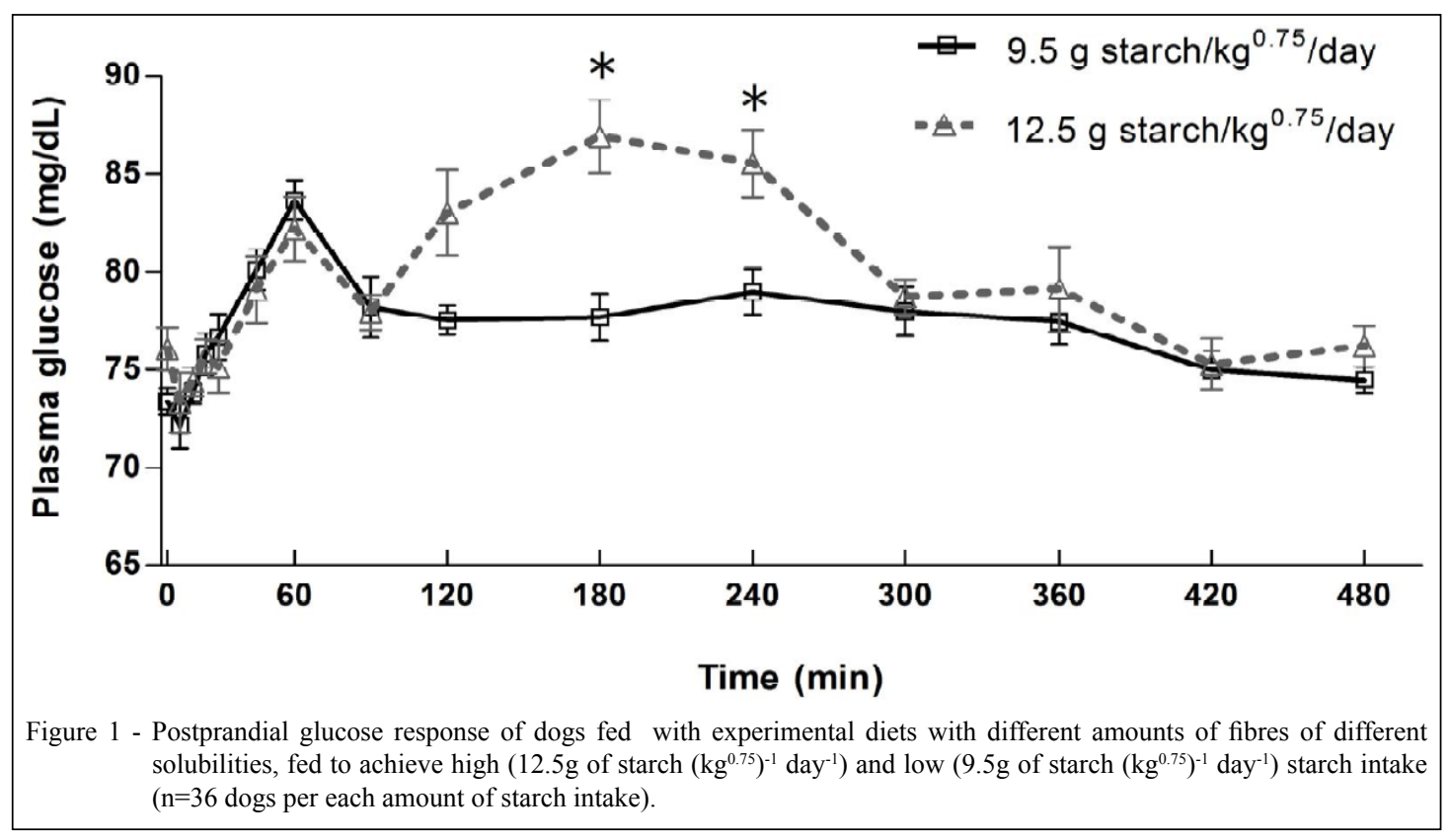

with the supplementation of the fibres in study, and only a reduction on plasma insulin was verified after guar gum dietary addition. Fibres, however, may have effect when supplemented to dogs with diabetes mellitus, in such particular health situation high fibre diets may reduce glucose concentration after the meal, helping the insulin administration in the control of glucose blood concentration (GRAHAM, et al., 2002). In addition, very high soluble fibre inclusion can change glucose meal response of health dogs, as demonstrated after the supplementation of 15 to $20 \%$ of guar gum (on DM basis) (BLAXTER et al., 1990). Such high inclusion rate, however, is not practical and induces other problems like soft stools, lower nutrient digestibility, and poor diet acceptance by the animal.

When the amount of starch intake increased, nearly all of the evaluated glucose-related traits of the dogs increased. This effect is consistent with what is known for humans (WOLEVER \& BOLOGNESI, 1996), and it occurred mainly due to the induction of a second glucose peak in the dogs between $120 \mathrm{~min}$ and $240 \mathrm{~min}$ after the meal. This second peak was higher and more prolonged than the first peak, and similar plasma glucose concentrations were found only $300 \mathrm{~min}$ after the meal when the dogs were fed with low and high dosages of starch. This response was independent of the fibre composition or amount in the diet; it occurred after the consumption of all of the evaluated diets. The amount of food provided to induce these changes can be considered physiologic because the dogs received the amounts of energy normally used to feed dogs for maintenance.
Previous studies of dogs (NGUYEN et al., 1994; HOENIG et al., 2001; CARCIOFI et al., 2008) evaluated their postprandial blood glucose and insulin responses after the consumption of commercial diets produced using different processing conditions, starch sources or fibre contents. However, the amount of starch intake was not different for these diets (CARCIOFI et al., 2008), or it was not described and evaluated in the experiments. NGUYEN et al., (1998b), have studied the effects of carbohydrate, protein and fat on the postprandial plasma glucose response of dogs, and they already concluded that the amount of starch consumed is the major determinant of glucose response to the meal. For humans, the starch intake corresponds to $46 \%$ to $64 \%$ of the glycaemic variation, being at times even more important than the type of starch or the other dietary compounds consumed (WOLEVER \& BOLOGNESI, 1996). The effect of the total amount of starch in a food or a meal is one of the important factors highlighted in the present study that may have several practical considerations for dogs. Replacing starch with fibre or even protein may be a practical way to reduce the glucose load of a meal. More than examining the specific physiological effects of these macronutrients, the substitution and reduction of the starch content seems to be important for producing foods that induce low glycaemic responses in dogs. Additionally, diets with low protein, fat and fibre contents based on starch may predispose dogs to an elevated postprandial glucose response and should be avoided in animals at risk of glucose tolerance 
disturbances, such as those that are obese, have diabetes mellitus, are of old age, and others.

One important limitation of the present study, however, is the measurement of only glucose. Insulin has a primary effect on blood glucose control, and knowing the postprandial pattern of the secretion of this hormone is very important to understanding carbohydrate metabolism (NGUYEN et al., 1994; NGUYEN et al., 1998b; HOENIG et al., 2001; CARCIOFI et al., 2008). It is possible that other responses could have been evaluated and understood if the insulin levels of the dogs had been determined, and this limitation suggests that the data from the present study should be interpreted with caution.

\section{CONCLUSION}

The data presented here suggest that a range in insoluble and soluble fibre intake do not change postprandial glucose response, and as verified for humans, the amount of starch intake is a main factor for the postprandial glucose response of healthy non-obese dogs.

\section{ACKNOWLEDGEMENTS}

To Guabi Pet Care, Campinas, SP, Brasil for the financial and technical support to the Laboratory of Research on Nutrition and Nutritional Diseases of Dogs and Cats, UNESP, Jaboticabal, Brasil, and Conselho Nacional de Desenvolvimento Científico e Tecnológico (CPNq) for the scholarship of Mariana Monti (number 832265/19993 ). None of the authors have any conflicts of interest.

\section{BIOETHICS AND COMMITTEE APPROVAL}

BIOSSECURITY

The Ethics Committee for Animal Well-Being of the College of Agrarian and Veterinary Sciences, Universidade Estadual Paulista approved all of the experimental procedures (Protocol number 0018435-08)

\section{REFERENCES}

AOAC (ASSOCIATION OF OFFICIAL ANALYTICAL CHEMISTS). Official methods of analysis. 16.ed. Washington, DC, USA, 1995, p. 1141.

BILIADERIS, C.G. The structure and interactions of starch with food. Canadian Journal of Physiology and Pharmacology, v.69, p.60-78, 1991. Available from: <http://www.ncbi.nlm.nih.gov/ pubmed/2036603>. Accessed: Jun. 15, 2014. doi: 10.1139/y91-011.

BLAXTER, A.C. et al. Dietary fibre and post prandial hyperglycaemia in normal and diabetic dogs. Journal of Small Animal Practice, v.31, p.29-233, 1990. Available from: <http:// onlinelibrary.wiley.com/doi/10.1111/j.1748-5827.1990.tb00790.x/ abstract>. Accessed: May 21, 2015. doi: 10.1111/j.17485827.1990.tb00790.x.
CARCIOFI, A.C. et al. Effects of six carbohydrates sources on dog diet digestibility and postprandial glucose and insulin response. Journal of Animal Physiology and Animal Nutrition, v.92, p.336-346, 2008. Available from: <http://www.ncbi.nlm.nih.gov/pubmed/18477314>. Accessed: Jun. 15, 2014. doi: 10.1111/j.1439-0396.2007.00794.x.

DIEZ, M. et al. The influence of sugar-beet fibre, guar gum and inulin on nutrient digestibility, water consumption and plasma metabolites in healthy Beagle dogs. Research in Veterinary Science, v.64, p.91-96, 1998. Available from: <http://www.ncbi. nlm.nih.gov/pubmed/9625462>. Accessed: May 21, 2015. doi: 10.1016/S0034-5288(98)90001-7.

FISCHER, M.M. et al. Fibre fermentability effects on energy and macronutrient digestibility, fecal traits, postprandial metabolite responses, and colon histology of overweight cats. Journal of Animal Science, v.90, p.2233-2245, 2012. Available from: <http:// www.ncbi.nlm.nih.gov/pubmed/22247109>. Accessed: Jun. 15, 2014. doi: $10.2527 /$ jas.2011-4334.

GRAHAM, P.A. et al. Influence of a high fibre diet on glycaemic control and quality of life in dogs with diabetes mellitus. Journal of Small Animal Practice, v.43, p.67-73, 2002. Available from: $<$ http://www.ncbi.nlm.nih.gov/pubmed/11873951>. Accessed: May 15, 2015. doi: 10.1111/j.1748-5827.2002.tb00031.x.

HEATON, K.W. et al. Particle size of wheat, maize, and oat test meals: effects on plasma glucose and insulin responses and on the rate of starch digestion in vitro. American Journal of Clinical Nutrition, v.47, p.675-682, 1988. Available from: <http://www.ncbi.nlm.nih. gov/pubmed/2451416>. Accessed: Jun. 15, 2014.

HENDRIX, D.L. Rapid extraction and analysis of nonstructural carbohydrates in plant tissues. Crop Science, v.25, p.1306-1311, 1995. Available from: <http://naldc.nal.usda.gov/download/43385/ PDF>. Accessed: May 21, 2015. doi: 10.2135/cropsci1993.00111 83X003300060037x.

HOENIG, M. et al. Glucose tolerance and lipid profiles in dogs fed different fibre diets. Journal of veterinary pharmacology and therapeutics, v.2, p.160-169, 2001. Available from: <http://www. ncbi.nlm.nih.gov/pubmed/19753709>. Accessed: Jun. 15, 2014.

LAFLAMME, D. Development and validation of a body condition score system for dogs. Canine Practice, v.22, p.10-15, 1997. Available from: <http://agris.fao.org/agris-search/search. do?recordID=US9742264 $>$. Accessed: Jun. 152014.

MASKELL, I.E. et al. Does the canning process alter the physiological effects of dietary fibre in the dog? Journal of Nutrition, v.124, p.2704S-2706S, 1994. Available from: <http:// jn.nutrition.org/content/124/12_Suppl/2704S.full.pdf $>$. Accessed: May 21, 2015. doi: 0022-3166/94.

MASSIMINO, S.P. et al. Fermentable dietary fibre increases GLP1 secretion and improves glucose homeostasis despite increased gastrointestinal glucose transportation capacity in healthy dogs. Journal of Nutrition, v.128, p.1786-1793, 1998. Available from: $<\mathrm{http}$ ://jn.nutrition.org/content/128/10/1786.long $>$. Accessed: Jun. 15, 2014. doi: 0022-3166/98.

NGUYEN, P. et al. Composition of meal influences changes in postprandial incremental glucose and insulin in health dogs. Journal of Nutrition, v.124, p.2707-2711, 1994. Available from: $<$ http://www.ncbi.nlm.nih.gov/pubmed/7996275>. Accessed: Jun. 15, 2014. doi: 0022-3166/94. 
NGUYEN, P. et al. Measurement of postprandial incremental glucose and insulin changes in healthy dogs: influence of food adaptations and length of time of blood sampling. Journal of Nutrition, v.128, p.2659-2662, 1998a. Available from: <http:// jn.nutrition.org/content/128/12/2659S.full >. Accessed: Jun. 15, 2014. doi: 0022-3166/98.

NGUYEN, P. et al. Glycemic and insulinemic responses after ingestion of commercial foods in healthy dogs: influence of food composition. Journal of Nutrition, v.128, p. 2654-2658, 1998 b. Available from: <http://jn.nutrition.org/content/128/12/2654S. full>. Accessed: Jun. 15, 2014. doi: 0022-3166/98

NRC (NATIONAL RESEARCH COUNCIL). Nutrient requirements of dogs and cats. Washington, DC: National Academy, 2006, p.424.

SA, F.C. et al. Enzyme use in kibble diets formulated with wheat bran for dogs: effects on processing and digestibility.
Journal of Animal Physiology and Animal Nutrition, v.97, Supp.1, p.51-59, 2013. Available from: <http://www.ncbi.nlm. nih.gov/pubmed/23639017>. Accessed: Jun. 15, 2014. doi: 10.1111/jpn. 12047 .

FEDIAF (EUROPEAN PET FOOD INDUSTRY FEDERATION). Nutritional guidelines for complete and complementary pet food for cats and dogs, 2008. Available from: <http://www.fediaf. org/self-regulation/nutrition/>. Online. Accessed: Jun. 15, 2015.

WOLEVER, T.M.S.; BOLOGNESI, C. Prediction of glucose and insulin responses of normal subjects after consuming mixed meals varying in energy, protein, fat, carbohydrate and glycemic index. Journal of Nutrition, v.126, p.2807-2812, 1996. Available from: $<$ http://www.ncbi.nlm.nih.gov/pubmed/8914952>. Accessed: Jun. 15, 2014. doi: 0022-3166/96.

ZOLMAN, J.F. Biostatistics: experimental design and statistical inference. New York: Oxford University, 1993, p. 343. 